\title{
Key Management Model Of Added Value In The Historical Tourist Attractions: The Case Studies The Emerald Buddha Temple Bangkok Thailand
}

\author{
Chayanan Kerdpitak, Valaya Alongkorn Rajabhat University, Thailand
}

\begin{abstract}
The promotion of the historical tourist attractions is an important mission that should be accomplished to ensure that the tourists have admired ancient sites that are valuable, rare, Inimitable and non-substitution. The tourists are thus enthusiastic to visit the ancient sites and willing to promote and encourage other tourists to visit these tourist attractions. By this reason, the objective of this research is to study the main factors affecting the added value of the tourist to the historical tourist attractions in Thailand. The factors include, Participation Management, Processes Management, Resource Management, Tourists Satisfaction, Tourist Attractions Differentiation and Added Value of Tourists.
\end{abstract}

In this study, the researcher has applied both quantitative and qualitative research methodologies using questionnaires and in-depth interview. The sample comprises visitors to the Temple of the Emerald Buddha. Meanwhile, the path analysis has been used to analyze the data. At the same time the researcher intends to propose the conceptual framework for this study with an aim to identify of the research question, there are any factors affecting to the added value of the visitors to the ancient sites. Moreover, the researcher has recommended 7 assumptions to find out the factors that have effects on the added value of the visitors to the ancient sites.

The result has shown that the Tourists satisfaction and the differentiation in tourist attractions have affected the visitors' added value with the significance level at 0.008. The result of this study can be used to set up the business operations policy of the Thai tourism business. The policy focuses on differentiation placing the development of tourist attractions as first priority followed by the environmental management, the promotion of tourist attractions and the renovation of ancient sites respectively.

Keywords: The Emerald Buddha Bangkok; The Historical Tourist Attractions

\section{INTRODUCTION}

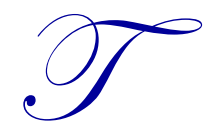

he tourism industry in Thailand is deemed as a main source of income; therefore, it is necessary to develop tourist attractions like the development of the other sectors of the country, so that the tourist attractions will draw the Thai and foreign tourists' interests and encourage them to travel more, resulting in more earnings and revolving funds in the tourist attractions and directly and indirectly developing the country. However, the country will not be able to make money from its tourism if the tourist attractions are abandoned, and their quality is not developed. Besides, the development must respond to the tourists' needs, (Department of Cultural Promotion, 2012, 2014).

Historical sites are one of the major sources of income from tourism. The historical sites are several hundred years old, and they are the archeological sites that cannot be found anywhere else. Some historical sites have art objects and antiques that cannot be imitated. If these historical sites are renovated and maintained for their previous splendor, they will become the sources of the added value of the country. Similarly, the Temple of the Emerald Buddha is one of the 
historical sites that are valuable, as the temple depicts the major culture of Thailand, (Department of Cultural Promotion, 2012; 2014).

Nevertheless, to add value to tourist attractions, tourists must be also taken into account. If business operators consider that the tourist attractions are valuable, but tourists do not see their value, they will not visit the sites, so it is not possible to make use of these sites.

\section{REVIEW OF THE LITERATURE}

\section{The Resource Base View Theory}

According to Competitive Advantage Theory, if a business has four valuable resources, it will take a competitive advantage. Such resources comprise 1) rare resource, 2) valuable resource, 3) Non-substitutable resource, and 4) Nonimitation resource. (Said \& Adham, 2010; Theriou, Aggelidie \& Theriou, 2009).

In addition, the business that has management efficiency should have the element of good financial resource and technology. Besides, reducing the cost of organization, making the differentiation of goods and services, and responding to the satisfaction of consumers should be taken into the serious consideration of the business. (Acedo, Barroco \& Galan, 2006; Barney, 1991; Barney, 2001a; Theriou et al.,2009).

\section{Competitive Theory}

In addition, according to the conception of Competitive Advantage, key factors which bring about the competitive advantage consist of controlling reduction in the cost of the organization, making the differentiation of the goods and services of the organization, and producing the utmost satisfaction of consumers. The three factors are regarded as the key indicator of the performance of the organization. If such factors have been successfully carried out by the organization, the organization will take the competitive advantage (Porter, 1980; Porter, 1985; Porter, 1990; Porter, 1998; Porter, 2001; Porter, 2008).

\section{Resource Management}

The resource management which is based on the Resource Base Theory must be conducted by the analysis of the importance of present circumstance, strength and weakness in order to create opportunities and to overcome obstacles to achieve in business. Another key factor of creating the competitive advantage is to maintain the existence of original resources by improving them to avoid their degeneration. Nevertheless, the improvement will not change the original nature of resources in order that such resources will become those which can be renewable. If the business has no important resource, this will be the competitive disadvantage of the business (Barney, 1991; Barney, 2001a; Barney, 2002; Chen, 1997; Hwang, Lee \& Chen, 2005).

H1: Resource Management has a positive effect on Tourist Attraction Differentiation

H2: Resource Management has a positive effect on Tourist Satisfaction

\section{Participation Management}

Participatory work will bring about a successful work. Participatory work is composed of work cooperation, resource sharing, brainstorming in the implementation of activities, equal benefit sharing, and participation in the development of cooperative network for prosperity. Besides, the adaptability of business to environment will result in business success. Historical tourism has emphasized the Participation Management since this kind of business needs a lot of stakeholders comprising tourist attractions, souvenir shops, transportation, including residents nearby tourist attractions, experts from government and private sectors. All these will drive the business to succeed or to fail. (Garbarino \& Johnson, 1999; Hwang et al. 2005; Kozak \& Rimmington, 2000; Macesich, 1994; Tuomela, 2002). 
H3: Participation Management has a positive effect on Tourist Attraction Differentiate

H4: Participation Management has a positive effect on Tourist Satisfaction

\section{Processes Management}

The process management is an order of work consisting of the sequence of priority of work to be done in order. In the business of historical tourism, the priority is to sequence the work starting from the arrangement of touring programs, travel, the provision of knowledge and understanding to tourists, the provision of tourism information, the advertisement of tourist attractions, and making the reputation of tourist attractions to be known and accepted by tourists (Chen, 1997; Dimanche \& Havitz, 1994; Hu \& Ritchie,1993; Kozak \& Rimmington, 2000).

H5: Processes Management has a positive effect on Tourist Attraction Differentiate

H6: Processes Management has a positive effect on Tourist Satisfaction

\section{Tourist Attractions Differentiation}

The conception of competition of differences in goods and services requires to make such a business to become the business that is different from general businesses. That is, touring to see a historical site which is a unique place and the only thing in the world. Besides, making a difference to the business which is regarded as the competitive advantage includes the provision of service different from that of other business in terms of the provision of excellent service or low cost service. The business that needs prosperity and long-term persistence must be able to make a difference to the business itself and to prevail over its competitors. (Dimanche \& Havitz, 1994; Dwyer, Forsyth \& Rao, 2001; Garbarino \& Johnson, 1999).

H7: Tourist Attractions Differentiate has a positive effect on Added Value of Tourist

\section{Tourist Satisfaction}

Responding to the satisfaction of customers is paramount. All types of goods and services, no matter how good they are, will be worthless if customers are not satisfied with them. Likewise, in the business of historical tourism, if tourists do not simply like the service, the business may not survive. Thus, the business needs to study the consumers' demand and always focuses on the issues which are the consumers' requirements. In addition, the business must respond to such requirements in order for prosperity (Chen, 1997; Fornell, 1992; Garbarino \& Johnson, 1999; Hwang et al., 2005; Kozak \& Rimmington, 2000).

H8: Tourist satisfaction has a positive effect on Added Value of Tourist 


\section{Conceptual of this Research}

Figure 1. Conceptual framework for research

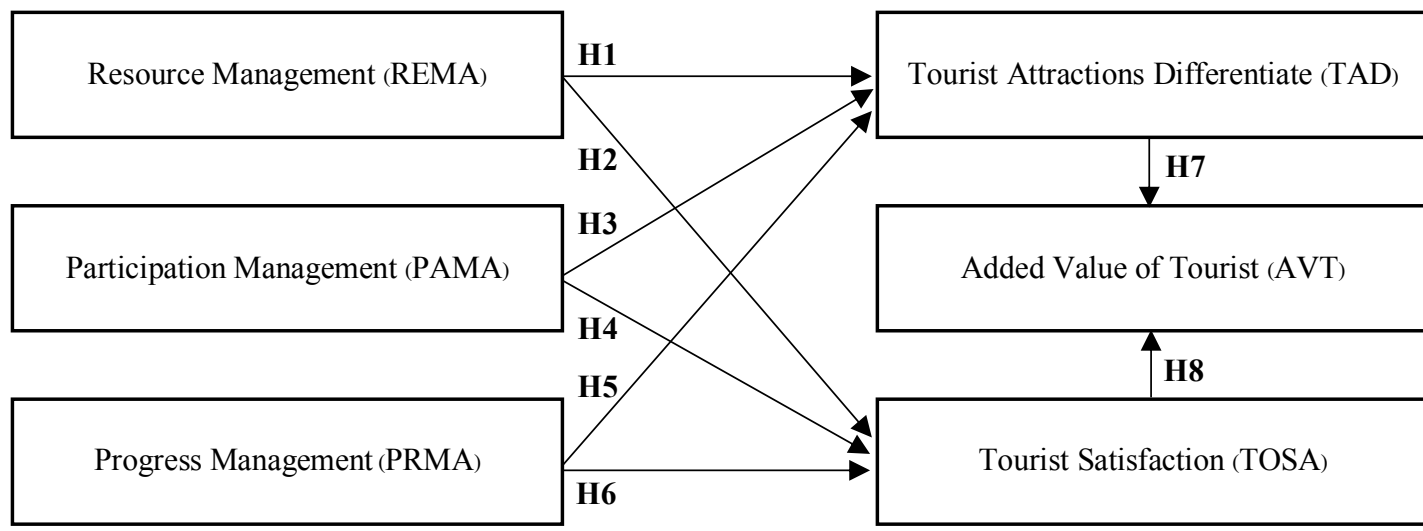

$T A D=\beta 0+\beta 1 R E M A+\beta 2 P A M A+\beta 3 P R M A \zeta$

$T O S A=\beta 4+\beta 5 R E M A+\beta 6 P A M A+\beta 7 P R M A \zeta$

$A V T=\beta 8+\beta 9 T A D+\beta 10$ TOSA $\zeta$

\section{METHODOLOGY}

In the current investigation, the researcher employed qualitative research and survey methods using a questionnaire. The study was divided into two steps. The first, a qualitative research study using an in-depth interview to obtain information for use in a quantitative research method. The second part of quantitative research questionnaire is divided into six main sections:

1) Participation Management

2) Processes Management

3) Resource Management

4) Tourist Attractions

5) Tourist Satisfaction

6) Added Value of Tourists

The population of study is that tourists who visit the Emerald Buddha Temple. The sample for this research was selected by purposive sampling and conducted interviews to obtain information for use in a quantitative research technique. Sample of quantitative research is tour the Emerald Buddha is form 400 questionnaires collected information (Cronbach, 1990).

In conducting this study, the population is the tourists who visited the Temple of the Emerald Buddha (Wat Phra Kaew). The exact number of population cannot be calculated. Therefore, the sample calculation is under the calculation method of infinite population. Under the sampling method, one group of tourists who travelled under the supervision of touring agency and another group of tourists who travelled by themselves, in the total number of 400 people, were selected. Descriptive Statistics and Path Analysis are applied in the data analysis (Cronbach, 1990). 


\section{FINDINGS}

The results of the interviews indicated that:

1. The participation of people and authorities in the area of tourism and that of people living around the area can drive the tourists to gain knowledge and to be satisfied with their touring. Besides, friendly greetings and hospitality can please the tourists.

2. The process management is a key subject-matter which educates the tourists about history in addition to historical introduction. The explanation of the arrangement of rituals in the temple area impresses the tourists and inspires them to visit again.

3. The resource management is very important because the tourists who visited the area of Wat Phra Kaew admired the beauty of the place which was hard to find and could not find the same in other tourist attractions. In addition, the resource management can satisfactorily preserve and maintain notable resources.

4. Identity and unique in the world are the difference of the historical site and resource for notable tourist attractions. This is because there are a lot of things which are different and unique, and can attract many tourists to visit the place.

Table 1. Factors derived from in-depth interviews to be used in formulating guideline for the solution of problems

\begin{tabular}{|c|c|c|c|}
\hline Variable & Mean & S.D. & Result \\
\hline \multicolumn{4}{|l|}{ Tourist attractions differentiation } \\
\hline Visitors to worship the sacred items that are unique, & 4.87 & 0.28 & Mostly \\
\hline Visitors are satisfied with this place that differ from other places & 4.76 & 0.38 & Mostly \\
\hline Visitors get to convenient to travel to the temple & 3.99 & 0.36 & Most \\
\hline Visitors travel the trip to the temple within one day & 4.11 & 0.44 & Most \\
\hline Visitors buy the sacred items for worship & 4.52 & 0.65 & Mostly \\
\hline \multicolumn{4}{|l|}{ Added value of tourists } \\
\hline Visitors can find something that cannot be imitated. & 4.01 & 0.44 & Most \\
\hline Visitors can see only one place in the world. & 4.12 & 0.55 & Most \\
\hline Visitors can see a property is rare and cannot found in other places & 4.45 & 0.39 & Mostly \\
\hline Visitors can see the beautiful things of value to the feeling. & 4.22 & 0.37 & Mostly \\
\hline \multicolumn{4}{|l|}{ Tourist Satisfaction } \\
\hline Visitors revisits again. & 3.43 & 0.39 & Most \\
\hline Visitors told the others people to look this tourist attraction. & 3.91 & 0.42 & Most \\
\hline Visitors have always a compliment and without any blame & 3.57 & 0.33 & Most \\
\hline Visitors appreciate the things there are cultural heritage. & 4.23 & 0.45 & Mostly \\
\hline \multicolumn{4}{|l|}{ Resources Management } \\
\hline The art objects must be well maintained, & 4.32 & 0.49 & Mostly \\
\hline The area should be always decorated and cleaned & 4.01 & 0.44 & Most \\
\hline The murals should be provided with maintenance instead of repainting & 3.87 & 0.53 & Most \\
\hline The area should not be any bad smells or waste & 3.55 & 0.64 & Most \\
\hline \multicolumn{4}{|l|}{ Participation Management } \\
\hline Visitors want to have tourist guides to explanations in this place & 3.38 & 0.54 & Most \\
\hline Visitors want to know the information, the details and the backgrounds of this temple & 4.33 & 0.44 & Mostly \\
\hline Potential activities in the area between the sacred. & 3.32 & 0.36 & Most \\
\hline Visitors want to people living in nearby areas to take care of tourists & 4.28 & 0.39 & Mostly \\
\hline Visitors want the temple staff to take care of tourists & 4.77 & 0.46 & Mostly \\
\hline \multicolumn{4}{|l|}{ Processes Management } \\
\hline Visitors want the information be disseminated to other different locations & 3.22 & 0.49 & Most \\
\hline Visitors want to promote the tourist attractions. & 3.25 & 0.29 & Most \\
\hline Visitors want the variety of activities in this area. & 4.65 & 0.43 & Mostly \\
\hline Visitors want to get the historical knowledge & 4.33 & 0.46 & Mostly \\
\hline Visitors should be get a variety of activities & 4.87 & 0.38 & Mostly \\
\hline Visitors want to participate in practice the activity in this temple & 4.38 & 0.47 & Mostly \\
\hline Visitors must be strict rules about dress in the temple & 4.54 & 0.38 & Mostly \\
\hline
\end{tabular}


Table 2. Findings on the basis of an overall analysis of the factors influencing Added value of tourist

\begin{tabular}{|c|c|c|c|c|c|c|c|c|}
\hline & \multicolumn{2}{|c|}{ Assumption } & & \multirow{2}{*}{$\mathbf{R}^{2}$} & \multirow{2}{*}{$\boldsymbol{\beta}$} & \multirow{2}{*}{$t$ - value } & \multirow[b]{2}{*}{ p - value } & \multirow{2}{*}{ Result } \\
\hline & Independent & Dependent & & & & & & \\
\hline H1 & REMA & TAD & Positively & 0.232 & 0.268 & 2.767 & 0.009 & Support \\
\hline $\mathrm{H} 2$ & REMA & TOSA & Positively & 0.324 & 0.296 & 2.099 & 0.012 & Support \\
\hline $\mathrm{H} 3$ & PAMA & TAD & Positively & 0.232 & 0.283 & 2.435 & 0.035 & Support \\
\hline $\mathrm{H} 4$ & PAMA & TOSA & Positively & 0.324 & 0.338 & 2.32 & 0.023 & Support \\
\hline H5 & PRMA & TAD & Positively & 0.232 & 0.333 & 2.139 & 0.001 & Support \\
\hline H6 & PRMA & TOSA & Positively & 0.324 & 0.246 & 2.465 & 0.004 & Support \\
\hline $\mathrm{H} 7$ & TAD & AVT & Positively & 0.222 & 0.354 & 2.375 & 0.006 & Support \\
\hline $\mathrm{H} 8$ & TOSA & AVT & Positively & 0.222 & 0.235 & 2.333 & 0.021 & Support \\
\hline
\end{tabular}

Figure 2. the Path Analysis Modeling

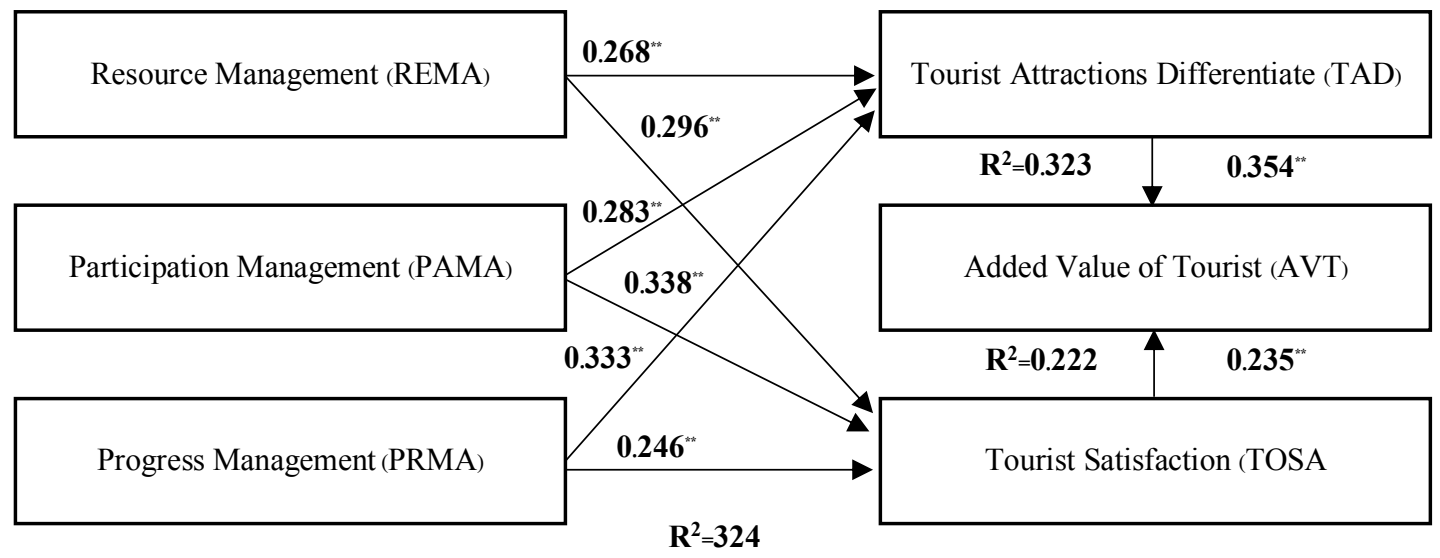

Table 3. Result of analysis on direct effect and indirect effect of path analysis modeling

\begin{tabular}{c|c|c|c|c|c|c|c|c|}
\hline \multirow{2}{*}{ Endogenous Variable } & \multirow{2}{*}{$\mathbf{R}^{2}$} & \multirow{2}{*}{ Effect } & REMA & PAMA & PRMA & TDA & TOSA \\
\hline \multirow{2}{*}{ AVT } & & DE & 0.000 & 0.000 & 0.000 & $0.354^{*}$ & $0.235^{* *}$ \\
\hline & \multirow{2}{*}{0.222} & IE & 0.164 & 0.179 & 0.176 & 0.000 & 0.000 \\
\hline & & TE & 0.164 & 0.179 & 0.176 & $0.354^{*}$ & 0.235 \\
\hline
\end{tabular}


Table 4. Result of analysis test validity and reliability with statistic method

\begin{tabular}{|c|c|c|}
\hline Variable & $\begin{array}{c}\text { Corrected } \\
\text { Item-Total } \\
\text { Correlation }\end{array}$ & $\begin{array}{c}\text { Cronbach's } \\
\text { Alpha }\end{array}$ \\
\hline Added Value of Tourists & & 0.9 \\
\hline AVT1: Visitors can find something that cannot be imitated. & 0.737 & \\
\hline AVT2: Visitors can see only one place in the world. & 0.706 & \\
\hline AVT3: Visitors can see a property is rare and cannot found in other places. & 0.769 & \\
\hline AVT4: Visitors can see the beautiful things of value to the feeling. & 0.775 & \\
\hline Tourist Satisfaction & & 0.911 \\
\hline TOSA1: Visitors revisits again. & 0.824 & \\
\hline TOSA2: Visitors told the others people to look this tourist attraction. & 0.741 & \\
\hline TOSA3: Visitors have always a compliment and without any blame & 0.728 & \\
\hline TOSA4: Visitors appreciate the things there are cultural heritage. & 0.781 & \\
\hline Tourist Attractions Differentiation & & 0.908 \\
\hline TDA1: Visitors to worship the sacred items that are unique. & 0.721 & \\
\hline TDA2: Visitors are satisfied with this place that differ from other places. & 0.809 & \\
\hline TDA3: Visitors get to convenient to travel to the temple. & 0.710 & \\
\hline TDA4: Visitors travel the trip to the temple within one day. & 0.768 & \\
\hline TDA5: Visitors buy the sacred items for worship. & 0.732 & \\
\hline Resources Management & & 0.889 \\
\hline REMA1: The art objects must be well maintained. & 0.748 & \\
\hline REMA2: The area should be always decorated and cleaned. & 0.740 & \\
\hline REMA3: The murals should be provided with maintenance instead of repainting. & 0.709 & \\
\hline REMA4: The area should not be any bad smells or waste. & 0.737 & \\
\hline Participation Management & & 0.859 \\
\hline PAMA1: Visitors want to have tourist guides to explanations in this place. & 0.731 & \\
\hline PAMA2: Visitors want to know the information, the details and the backgrounds of this temple. & 0.734 & \\
\hline PAMA3: Visitors want to people living in nearby areas to take care of tourists. & 0.738 & \\
\hline PAMA4: Visitors want the temple staff to take care of tourists. & 0.741 & \\
\hline Processes Management & & 0.868 \\
\hline PRMA1: Visitors want the information be disseminated to other different locations. & 0.758 & \\
\hline PRMA2: Visitors want to promote the tourist attractions. & 0.784 & \\
\hline PRMA3: Visitors want the variety of activities in this area. & 0.702 & \\
\hline PRMA4: Visitors want to get the historical knowledge. & 0.706 & \\
\hline PRMA5: Visitors should be get a variety of activities. & 0.723 & \\
\hline PRMA6: Visitors want to participate in practice the activity in this temple. & 0.727 & \\
\hline PRMA7: Visitors must be strict rules about dress in the temple. & 0.728 & \\
\hline
\end{tabular}

\section{DISCUSSION OF FINDINGS}

For the Differences of Tourist Attractions, tourists care for and are satisfied with the tourist attractions that differ from other places. In addition, the places cannot be found anywhere else, or they cannot be replaced by other places. Traveling to the Temple of the Emerald Buddha allows the tourists to worship the sacred items that are unique, appreciate splendid art objects and buy the sacred items for worship. Additionally, it is convenient to travel to the temple, as the trip to the temple is possible within one day.

For the Added Value of Tourist Attractions, the tourists are happy to see ancient art objects, sacred items and gorgeous ancient murals, and these tourist sites cannot be found anywhere else in the world, as they cannot be imitated. Moreover, these objects and murals are rare items. They are worth seeing and remembering.

For Tourists' Satisfaction, the tourists visiting the tourist attractions admire the cultural heritages that are unique, and they cannot complain about the tourist sites. Most of the tourists want to come back and tell other people about the splendor of the places and their uniqueness. 
For Resources Management, the tourists think that the art objects must be well maintained, and they must be always splendid. Furthermore, the murals should be provided with maintenance instead of repainting. Meanwhile, the area should be always decorated and cleaned. There should not be any bad smells or wastes in the area.

For Tourism Participation Management, the tourists want to have tourist guides to give them explanations in the temple. They want to know the information, the details and the backgrounds of the items in the temple. Also, they want the temple staff to take care of tourists and people living in nearby areas.

For the management process of the tourist attraction, the tourists still require that the information be disseminated to other different locations, so that the place is well recognized by tourists. The tourists should be provided with the history. Meanwhile, there should be a variety of activities, such as worshipping ceremony and benediction. These activities should draw tourists' participation, promote historical awareness and increase sales among tourists like those in other tourist attractions.

\section{CONCLUSION}

Findings indicate that factors influencing Added Value of Tourist can be used as guidelines in solving problems organizations are currently facing. The five main factors are the following:

1. Tourist Attractions Differentiate

2. Tourist Satisfaction

3. Resource Management

4. Participation Management

5. Processes Management

Each factor involves significant aspects with the total being 25. All aspects should be addressed if problems are to be successfully solved over the long haul.

In addition, it was also found that Added Value of Tourist can be judged by reference to four indicators as follows:

1. Compliments on the service

2. Recommending others to visit

3. Encouraging the tourists to visit again

4. Absence of any blame

Each indicator involves significant subsidiary aspects, the total comprising.

\section{AUTHOR BIOGRAPHY}

Chayanan Kerdpitak is a head of Master of Business Administration Program (MBA) and Management committee of Doctor of Business Administration Program (DBA) at Valaya Alongkorn Rajabhat University in Thailand. She received a Ph.D. in the field of Business at Ramkhamhaeng University, Bangkok, Thailand. In addition, she graduated a B.B.A. and M.B.A. in Business Administration from the Ramkhamhaeng University, Bangkok, Thailand (Marjor in Marketing).

\section{REFERENCES}

Acedo, F. J., Barroso, C. \& Galan, J. L. (2006). The resource-based theory: Dissemination and main trends. Strategic Management Journal, 27(7), 621-636

Barney, J. B. (1991). Firm resources and sustained competitive advantage. Journal of Management, 17(1), 99-120.

Barney, J. B. (2001a). Resource-based theories of competitive advantage: A ten-year retrospective on the resource-base view Journal of Management, 27, 643-649.

Barney, J. B. (2002). Gaining and sustaining competitive advantage. $2^{\text {nd }}$ Ed. Upper Saddle River, NJ: Prentice Hall.

Chen, K. J. (1997). The effect of satisfaction and familiarity on intention: Multiple-destination context Kuang-Jung Chen. Journal of International Consumer Marketing, 10(1/2).

Cronbach, J. (1990). Essential of psychology testing. New York: Hampercollishes. 
Department of Cultural Promotion. (2012). http//www.mots.go.th/more_news. (10 May 2012)

Department of Cultural Promotion. (2014). http//www.mots.go.th/more_news. (20 Jan 2014)

Dimanche, F. \& Havitz, M. E. (1994). Consumer behavior and tourism: Review and extension of four study areas. Journal of Travel and Tourism Marketing, 3(3), 37-57.

Dwyer, L., Forsyth, P. \& Rao, P. (2001). The price competitiveness of travel and tourism: A comparison of 19 destinations. Tourism Management, 21(1), 9-22.

Fornell, C. (1992). A national customer satisfaction barometer: The Swedish experience. Journal of Marketing, 56(1), 6-21.

Garbarino, E. \& Johnson, M. S. (1999). The different roles of satisfaction, trust, and commitment in customer relationships. Journal of Marketing, 63, 70-87.

Hu, Y. \& Ritchie, J. R. B. (1993). Measuring destination attractiveness: A contextual approach. Journal of Travel Research, $32(2), 25-34$.

Hwang, S. N., Lee, C. \& Chen, H. J. (2005). The relationship among tourists' involvement, place attach and interpretation satisfaction in Taiwan's national parks. Tourism Management, 26, 143-156.

Kozak, M. \& Rimmington, M. (2000). Tourist satisfaction with Mallorca, Spain as an off-season holiday destination. Journal of Travel Research, 38(February), 260-269.

Macesich, G. (1994). Succession states and cooperation theory: A model for Eastern Europe. USA, 3-27.

Ministry of Culture. (2012). http//www. M-culture.go.th/knowledge_region_all. (12 May 2012).

Ministry of Tourism \& Sports. (2012). http//www.mots.go.th/more_news. (1 May 2012)

Porter, M. E. (1980). Generic competitive strategies: Competitive strategy: Techniques for analyzing industries and competitors. New York: The Free Press.

Porter, M. E. (1985). Competitive Advantage: Creating and sustaining superior performance. New York: The Free Press.

Porter, M. E. (1990). The competitive advantage of nations. New York: The Free Press.

Porter, M. E. (1998). Competitive advantage: Creating and sustaining superior. NewYork: The Free Press.

Porter, M. E. (2001). Strategy and the Internet. Harvard Business Review, 79(3) 63-78.

Porter, M. E. (2008). The five competitive forces that shape strategy. Harvard Business Review, 86(1), 78-93.

Said, M. F. \& Adham, K. A., (2010). Online mobile content innovations and industry structure: Implications for firms 'strategies. International Journal of Economics and Management, 4(1), 101-119.

Theriou, N. G., Aggelidis, V. \& Theriou, G. N. (2009) . A theoretical framework contrasting the resource-based perspective and the knowledge-based view. European Research Studies, 7(3), 177-190.

Tuomela, R. (2002). The philosophy of social practices: A collective acceptance view. Cambridge University Press. 


\section{NOTES}

